\title{
RURAL BANDERS IN THE SASKATOON AREA*
}

C. STUART HOUSTON and MARY I. HOUSTON, 863 University Drive, Saskatoon, SK S7N 0J8

A small coterie of Saskatchewan residents, mainly farmers, took an early interest in bird banding. ${ }^{3}$ This article features rural banders within the Saskatoon Bird Area, a 68.5 by 63 mile square with Saskatoon near its centre.

Four of the rural bird banders were farmers; three were concentrated in a small area between Hepburn and Dalmeny and the fourth was active briefly at Elstow. In addition, Fred Bard at the Provincial Museum in Regina released 64 banded crows and 3 magpies in the Saskatoon area as a contribution to the Saskatchewan Game Branch campaign to shoot crows in the hope of decreasing duck nest depredation.

Philip Siemens, 1897-1990, permit \# 00022

Philip Siemens was the first of the rural banders in the Saskatoon Bird Area (SBA). He was born at Plum Coulee, Manitoba, on April 1, 1897, the sixth of ten children. In 1903, Philip's parents moved to their parents' farm a half mile west of the village of Rosthern, (then part of the North-west Territories) and in 1914, after three more moves, they settled on a farm a mile north of Hepburn, barely outside the northern edge of the SBA. Philip was farming east of Hepburn when he married in 1923. His wife died three years later. His second marriage in 1933 was to Tena Rempel of Great Deer, Saskatchewan.

Philip began banding birds in 1928 and continued this hobby for ten years, banding a total of 416 individuals of 32 species. Of his ten recoveries, nine were "direct," i.e., within six months of banding. During the years when many farmers on both sides of the $49^{\text {th }}$ parallel thought "the only good hawk

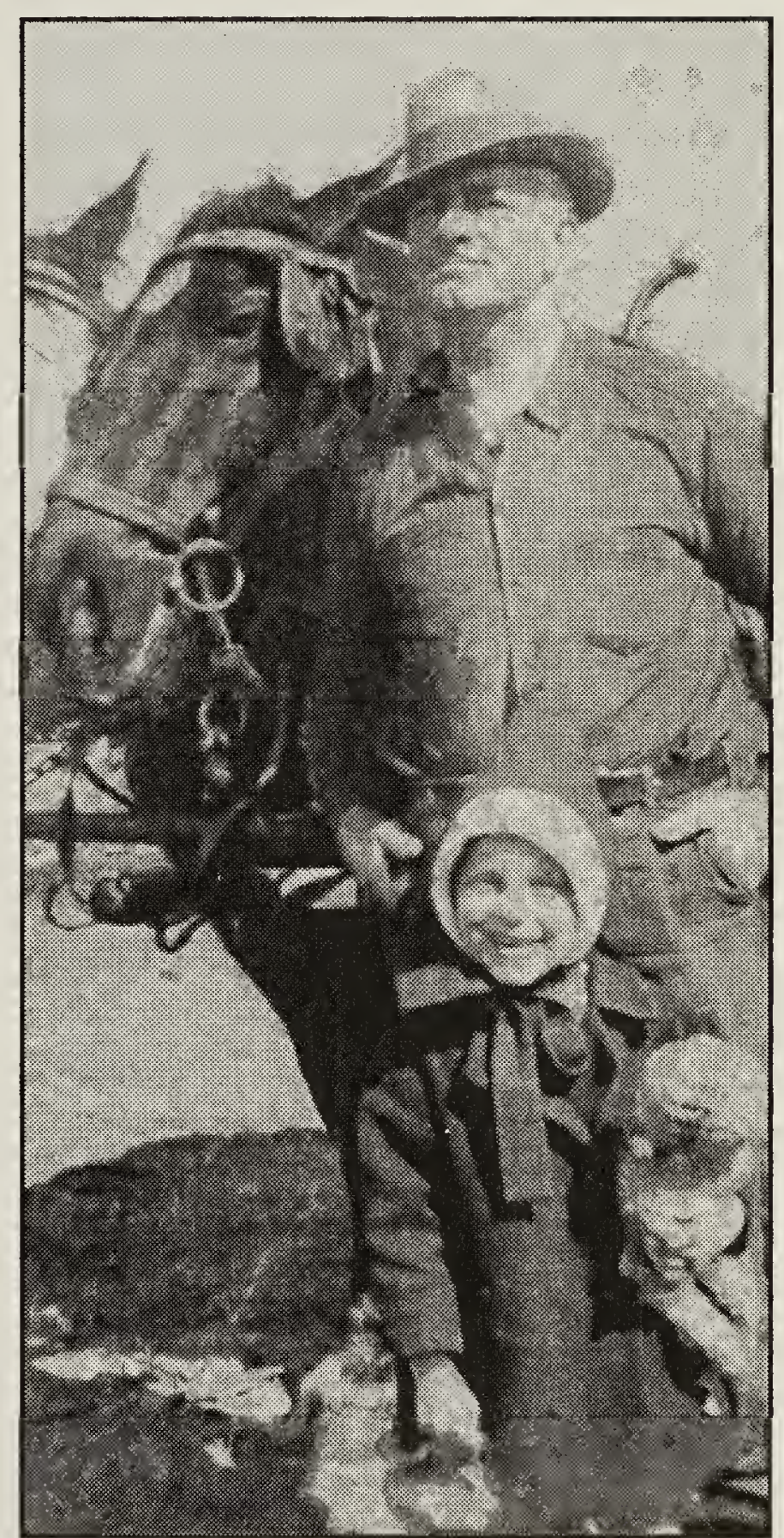

Philip Siemens and daughter Phyllis, 1930s

is a dead hawk," no fewer than four of the six Red-tailed Hawks from nests on his farm in three different years were reported shot in the United States: one each in Iowa and Oklahoma, and two in Texas. Northern Shovelers were shot not far away at Waldheim and Marcelin, Saskatchewan. A Loggerhead Shrike at Cross Timbers, Missouri, and a Yellow-shafted Flicker at 
Metz, Missouri, were both found dead. A Common Grackle at North Battleford was the only "indirect" recovery, having survived just over one year; it had a broken leg.

Among the postcards used to inform the bander of a recovery was one, now in our possession thanks to Philip's daughter Phyllis, that had not been entered in the computer system. It reports that Professor Wyman R. Green, a bander, caught a small bird carrying band $\mathrm{C} 4240$ in his traps at Soddy, Tennessee, on the suspiciously early date of 28 September. This band had been placed on a Common Redpoll by Siemens at Hepburn on 2 February that year. The identification at banding is unquestioned, but might Professor Green have read the band number incorrectly? We will never know.

Tena Siemens died in 1979. In 1987, Philip went to Crooked River, Saskatchewan, to live with his daughter Margaret and her husband, Morley Mehler. $\mathrm{He}$ moved into the nursing home at Arborfield in 1989, and died on 1 May 1990, at the age of 93 years. His nephew's eulogy described his uncle's lifelong loves as reading, poetry, and nature. Philip Siemens was hospitable, devout, generous, serene and a patient, venerable man.

\section{Abram S. Loewen, 1918- 1993, permit \# 00357}

Abram was a nephew of Philip Siemens. His father farmed 2 miles south and 1.5 miles east of Hepburn. From 1935 through 1938, Abram banded 166 individuals of 22 species. Loggerhead Shrikes were common then, allowing him to band 35 nestlings compared to 28 American Robins, his second highest total. He caught three Snow Buntings with a drop trap, a wire cage which fell over bait when he pulled the string attached to a prop holding up one end of the trap. His younger brother John, now a retired high school teacher in Saskatoon, remembers well how he helped catch adult Yellow-shafted Flickers by placing a jar over the hole, tapping the tree, and capturing the bird in the jar. Eleven flickers were banded, in fourth place following 14 House Wrens.

One flicker, banded on 7 June, was shot the same year in early October, about 31 miles west of Okmulgee, Oklahoma. A Loggerhead Shrike was killed in a severe thunderstorm nearly four years after banding, on 8 April, near Nocoma, Texas.

Abe Loewen moved into Saskatoon in 1940 and later was employed as a school custodian. He died on 11 February 1993.

\section{Henry D. Goosen, 1916-1998,} permit \# 00215

Henry D. Goosen of Dalmeny banded 217 birds of 22 species between 1934 and 1938. He knew the Loewen boys at Hepburn, 8 miles north and two miles east of the Goosen farm; in fact Henry's brother married Abe and John Loewen's sister, Kay. Henry used a drop trap to capture 98 Slate-colored Juncos, 16 White-throated, 2 White-crowned and 4 American Tree sparrows during migration, and in winter caught 28 Snow Buntings and 10 Common Redpolls.

Two of his birds were reported as "returns," that is, recaptured the year after banding. An adult female Common Grackle banded on 11 May 1935 in a drop trap was recaught by the same means on 11 June 1936. An adult Barn Swallow caught on 12 June 1934 was recaught on 17 July 1935. Henry had no distant recoveries.

Henry left the farm to work in the aircraft industry in Seattle during the Second World War; after the war he was a carpenter at Mission, British Columbia, where he died in 1998 .

John Dick, Jr., Elstow, (dates of birth and death unknown), permit \# 00034

In 1929, on a farm two miles north and two miles west of Elstow, John Dick, Jr. banded 28 individuals of 7 species: 10 Mallards, 2 Northern Pintails, 4 Common 
Nighthawks, I Red-winged Blackbird, 3 Common Grackles, 6 House Sparrows and two fledgling "Barn Owls", "too young to fly" on 24 June. The latter were probably Great Horned Owls using a barn as a nest site, but if so he applied too small a band (the size specified in the banding manual for the Barn Owl, the same size used for pintails and Mallards). That size of band was also given to what he called "nighthawks," but would not have stayed put on a nighthawk as it was a size appropriate for Swainson's Hawks. We conclude that Dick, in contrast to other early Saskatchewan banders, made two serious errors in bird identification.

Three of Dick's ducks were shot, two during the first hunting season: a Northern Pintail shot locally and a Mallard in South Dakota, and in the 1930 season, a Mallard in Colorado. Dick then moved to Fairholme, Saskatchewan and discontinued banding.

Fred G. Bard, Jr., 1908-1989,

permit \# 00151

E.R Kalmbach of the United States Biological Survey conducted studies near Kinistino and Prince Albert in 1934 and 1935. He reported that crows destroyed at least $31 \%$ of duck nests each year. ${ }^{4}$ As a result, Fred Bard of the Provincial Museum in Regina undertook a crow control program for three years, 1936 - 1938. Bard's program, which awarded cash prizes to individuals who shot crows wearing leg bands, was a sincere but misguided attempt to halt a decline in waterfowl numbers.

Adult crows were trapped (for example, 250 in 1938), and then released widely throughout Saskatchewan, usually two at each ten-mile interval along major highways. ${ }^{1,2}$ However, there was an unforeseen flaw in the methodology. Instead of shooting crows at random, hunters soon learned to seek out crows with bands and shoot them selectively, continuing to do so even after Bard, in desperation, painted the bands black to make them less obvious in sunlight!

A province-wide "contest" was funded by the Saskatchewan Fish and Game League and Ducks Unlimited. Everyone submitting a crow band received a prize: 111 entrants received the minimum $\$ 1,19$ received $\$ 5,3$ got $\$ 10$, and 3 got $\$ 25$. The top prizes, one each, were $\$ 50$ and $\$ 100$. Remember that a late-1930s dollar had purchasing power equivalent to about $\$ 20$ in 2002! Eleven others turned in magpie bands as part of the same campaign, but no prizes were listed for this species.

Of 64 crows released by Bard or his assistants in the SBA, 16 were shot, 14 within the area, one in South Dakota and one in Texas. Of 3 magpies released in the SBA, the one released at Warman on 15 July 1937 was shot in the same locality the same day!

1. HOUSTON, C.S. 1969. Recoveries of the Common Crow banded in Saskatehewan. Blue Jay 27:84-88.

2. HOUSTON, C.S. 1970. Saskatehewan bird banders \#13: Fred G. Bard. Blue Jay 28:150-156.

3. HOUSTON, C.S. 1990. Early Saskatehewan bird banders in perspeetive. Blue Jay 48:204-208.

4. KALMBACH, E.R. 1937. Crow-waterfowl relationships based on preliminary studies on Canadian breeding grounds. U.S. Dept. Agriculture Circular 433.

* Number 19 in a series of biographies of Saskatchewan bird banders 